Article

\title{
Purification and Identification of Antioxidant Peptides from Protein Hydrolysate of Scalloped Hammerhead (Sphyrna lewini) Cartilage
}

\author{
Xue-Rong $\mathrm{Li}^{1}$, Chang-Feng $\mathrm{Chi}^{1, *}, \mathrm{Li} \mathrm{Li}^{1}$ and Bin Wang ${ }^{2, *}$ \\ 1 School of Marine Science and Technology, Zhejiang Ocean University, 1st Haidanan Road, Changzhi Island, \\ Lincheng, Zhoushan 316022, China; xuerong10312@163.com (X.-R.L.); wenwenlili@163.com (L.L.) \\ 2 School of Food and Pharmacy, Zhejiang Ocean University, 1st Haidanan Road, Changzhi Island, Lincheng, \\ Zhoushan 316022, China \\ * Correspondence: chichangfeng@hotmail.com (C.-F.C.); wangbin4159@hotmail.com (B.W.); \\ Tel.: +86-580-255-4818 (C.-F.C.); +86-580-255-5085 (B.W.); \\ Fax: $+86-580-255-4818$ (C.-F.C.); $+86-580-255-4781$ (B.W.)
}

Academic Editor: Paul Long

Received: 26 August 2016; Accepted: 18 February 2017; Published: 1 March 2017

\begin{abstract}
The aim of this study was to purify and identify peptides with antioxidant properties from protein hydrolysate of scalloped hammerhead (Sphyrna lewini) cartilage. Cartilaginous proteins of the scalloped hammerhead were extracted by guanidine hydrochloride, and three antioxidant peptides, named enzymolysis peptide of scalloped hammerhead cartilage A (SCPE-A), SCPE-B and SCPE-C, were subsequently isolated from the hydrolysate of the cartilaginous proteins using ultrafiltration and chromatography. The amino acid sequences of SCPE-A, SCPE-B and SCPE-C were identified as Gly-Pro-Glu (GPE), Gly-Ala-Arg-Gly-Pro-Gln (GARGPQ), and Gly-Phe-Thr-Gly-Pro-Pro-Gly-Phe-Asn-Gly (GFTGPPGFNG), with molecular weights of $301.30 \mathrm{Da}$, 584.64 $\mathrm{Da}$ and $950.03 \mathrm{Da}$, respectively. As per in vitro activity testing, SCPE-A, SCPE-B and SCPE-C exhibited strong scavenging activities on 2,2-diphenyl-1-picrylhydrazyl radicals (DPPH•) (half elimination ratio $\left(\mathrm{EC}_{50}\right) 2.43,2.66$ and $\left.1.99 \mathrm{mg} / \mathrm{mL}\right)$, hydroxyl radicals $(\mathrm{HO} \bullet)\left(\mathrm{EC}_{50} 0.28,0.21\right.$ and $0.15 \mathrm{mg} / \mathrm{mL}$ ), 2,2'-azino-bis-3-ethylbenzothiazoline-6-sulfonic acid radicals (ABTS $\bullet$ ) $\left(\mathrm{EC}_{50} 0.24,0.18\right.$ and $0.29 \mathrm{mg} / \mathrm{mL})$, and superoxide anion radicals $\left(\mathrm{O}_{2}^{-} \bullet\right)\left(\mathrm{EC}_{50} 0.10,0.14\right.$ and $\left.0.11 \mathrm{mg} / \mathrm{mL}\right)$. In addition, SCPE-A showed inhibition activity similar to butylated hydroxytoluene (BHT) in lipid peroxidation in a linoleic acid model system. The amino acid residues of Gly, Pro and Phe could positively influence the antioxidant activities of GPE, GARGPQ and GFTGPPGFNG. These results suggested that GPE, GARGPQ and GFTGPPGFNG might serve as potential antioxidants and be used as food additives and functional foods.
\end{abstract}

Keywords: scalloped hammerhead (Sphyrna lewini); cartilage; peptide; antioxidant activity

\section{Introduction}

Oxidation is an important factor in the food industry because it causes a loss of nutrition, color and functionality, as well as undesirable off-flavors and toxic compounds, which further induce the deterioration of food. Furthermore, the accumulation of toxic products is dangerous to the health of consumers [1,2]. Therefore, the inhibition of free radical formation and oxidation reactions play an important role in preventing or retarding the autoxidation of food components [3]. Many synthetic antioxidants, including butylated hydroxytoluene (BHT), butylated hydroxyanisole (BHA), and tertiary butylhydroquinone (TBHQ), are widely used in the food industry for preservation and to retard lipid oxidation $[4,5]$. However, the dosages of the synthetic antioxidants are under strict regulation due to 
their potential health hazards and toxic effects [6,7]. Therefore, there has been a large amount of interest in researching safe antioxidants from natural sources as an alternative to synthetic antioxidants [8].

In recent years, peptides with different activities, including anticancer, antioxidant, antimicrobial, antihypertensive, and mineral-binding properties, have been isolated from various bioresources, such as byproducts from the fish processing industry [9]. Antioxidant peptides have drawn great attention and have been extensively reported as free radical scavengers, peroxide decomposers, metal inactivators and oxygen inhibitors to protect food and organisms from reactive oxygen species (ROS) [8,10]. Arg-Gln-Ser-His-Phe-Ala-Asn-Ala-Gln-Pro (RQSHFANAQP), with molecular weight (MW) $1155 \mathrm{Da}$, from the protein hydrolysate of chickpeas showed significant dose-dependent scavenging activities on hydroxyl radicals $(\mathrm{HO} \bullet)\left(\mathrm{EC}_{50} 2.03 \mu \mathrm{mol} / \mathrm{mL}\right), 2$,2-diphenyl-1-picrylhydrazyl radicals (DPPH•) $\left(\mathrm{EC}_{50} 3.15 \mu \mathrm{mol} / \mathrm{mL}\right)$ and 2, 2'-azino-bis-3-ethylbenzothiazoline-6-sulfonic acid radicals $\left(\mathrm{ABTS}^{+} \bullet\right)\left(\mathrm{EC}_{50} 2.31 \mu \mathrm{mol} / \mathrm{mL}\right)$ [10]. Asp-Leu-Glu-Glu (DLEE), with MW 504.2 Da, was confirmed to be one of the main antioxidant peptides generated in dry-cured Xuanwei ham, and its DPPH• scavenging rate was $74.45 \%$ at $0.5 \mathrm{mg} / \mathrm{mL}$ [9]. Phe-Ile-Met-Gly-Pro-Tyr (FIMGPY), Gly-Pro-Ala-Gly-Asp-Tyr (GPAGDY) and Ile-Val-Ala-Gly-Pro-Gln (IVAGPQ), with MWs of 726.90 Da, 578.58 Da and 583.69 Da, respectively, showed strong scavenging activities on DPPH• (EC 50 3.5768, 6.0147 and $6.733 \mathrm{M}), \mathrm{HO} \bullet\left(\mathrm{EC}_{50} 4.1821,6.7752\right.$ and $\left.8.6176 \mathrm{M}\right)$, superoxide anion radicals $\left(\mathrm{O}_{2}^{-} \bullet\right)$ $\left(\mathrm{EC}_{50} 2.2149,2.8691\right.$ and $\left.3.1181 \mathrm{M}\right)$ and $\mathrm{ABTS}^{+} \bullet\left(\mathrm{EC}_{50}\right.$ 1.4307, 1.3308 and 2.2101 M) [11]. In addition, FIMGPY induced HeLa cell apoptosis by up-regulating the Bax (B-cell lymphoma 2 (Bcl-2) assaciated $X$ protein)/Bcl-2 ratio and caspase-3 activation [12]. Structure-activity studies on the antioxidant peptides suggested that the peptide length and the composition and position of amino acids in a peptide sequence are important determinants of the bioactivity of a specific peptide $[8,13,14]$.

Cartilage is a form of connective tissue that is chemically abundant in bioactive components, and many cartilaginous proteins, low MW proteins, glycoproteins, and peptides have been prepared from various soft bone fish sources, such as bamboo and blacktip sharks [15], Prionace glauca [16], Amur sturgeon [17], spotless smoothhound [7], and silvertip shark [18]. Current research has shown that those active substances could be used as angiogenesis inhibitors, tumor cells inhibitory factors, antioxidants, immune regulatory factors, and anti-invasion factors for the treatment of some diseases, especially in tumor therapy and prevention. Scalloped hammerhead (Sphyrna lewini), belonging to the family Triakidae, is a commercially valuable fishery resource. At present, large quantities of muscle protein and cartilages (except the cartilages from fins) from scalloped hammerhead are not used efficiently. In our previous research, three antioxidant peptides, Trp-Asp-Arg (WDR), Pro-Tyr-Phe-Asn-Lys (PYFNK) and Leu-Asp-Lys (LDK), were isolated from the hydrolysate of scalloped hammerhead muscle, and WDR, PYFNK and LDK exhibited good scavenging activities on DPPH• $\left(\mathrm{EC}_{50} 3.63,4.11\right.$ and $3.06 \mathrm{mg} / \mathrm{mL}), \mathrm{HO} \bullet\left(\mathrm{EC}_{50} 0.15,0.24\right.$ and $\left.0.17 \mathrm{mg} / \mathrm{mL}\right), \mathrm{ABTS}^{+} \bullet\left(\mathrm{EC}_{50} 0.34,0.12\right.$ and $\left.0.19 \mathrm{mg} / \mathrm{mL}\right)$, and $\mathrm{O}_{2}^{-} \bullet\left(\mathrm{EC}_{50} 0.09,0.11\right.$ and $\left.0.12 \mathrm{mg} / \mathrm{mL}\right)[19,20]$. Acid-soluble collagen and its hydrolysate were prepared from scalloped hammerhead cartilage [21]. However, to the best of our knowledge, there is no research focusing on the antioxidative peptides in scalloped hammerhead cartilage. Thus, in this study, three novel antioxidant peptides were isolated from the protein hydrolysate of scalloped

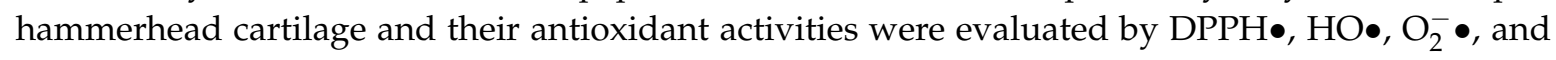
$\mathrm{ABTS}^{+} \bullet$ scavenging and lipid peroxidation inhibition assays.

\section{Results and Discussion}

\subsection{Preparation of the Protein Hydrolysate of Scalloped Hammerhead Cartilage (SHCH)}

Proteins in raw and processed foods possess antioxidant peptide sequences and structural domains, and enzymatic hydrolysis is considered as an attractive way for releasing those active fragments without impairing their nutritional value and without leaving residual organic solvents and toxic chemicals in the final product [22]. In addition, protein hydrolysates using different proteases exhibit different antioxidant activities against various antioxidant systems because the peptides are 
different in terms of chain length and amino acid sequence [1,23]. Therefore, five proteases including papain, alcalase, trypsin, pepsin, and neutrase were used to hydrolyze the cartilaginous proteins of scalloped hammerhead. HO• scavenging assay is quick, convenient, and efficient in predicting the antioxidant activities of protein hydrolysates and purified peptides. As a consequence, HO• was used to evaluate the antioxidant activity of compounds to act as free radical scavengers or hydrogen donors, and the results are shown in Table 1.

Table 1. Hydroxyl radical (HO•) scavenging activity of the protein hydrolysate of scalloped hammerhead cartilage using different proteases $(c=15 \mathrm{mg}$ protein $/ \mathrm{mL})$.

\begin{tabular}{|c|c|c|c|c|}
\hline Protease & Enzymolysis Condition & $\begin{array}{l}\text { Yields (g/100 g } \\
\text { Cartilage) }\end{array}$ & $\begin{array}{c}\text { Degree of } \\
\text { Hydrolysis (DH\%) }\end{array}$ & $\begin{array}{c}\text { HO• Scavenging } \\
\text { Rate }(\%)\end{array}$ \\
\hline Papain & $\begin{array}{c}\mathrm{pH} 7.0,60^{\circ} \mathrm{C}, 4 \mathrm{~h}, \\
\text { total enzyme dose } 2.5 \%\end{array}$ & $1.93 \pm 0.08^{a}$ & $18.33 \pm 0.25^{a}$ & $34.85 \pm 1.05^{\mathrm{a}}$ \\
\hline Alcalase & $\begin{array}{l}\mathrm{pH} 8.0,50{ }^{\circ} \mathrm{C}, 4 \mathrm{~h}, \\
\text { total enzyme dose } 2.5 \%\end{array}$ & $1.96 \pm 0.10^{\mathrm{a}, \mathrm{b}}$ & $21.37 \pm 0.35^{b, c}$ & $54.76 \pm 1.94^{b}$ \\
\hline Trypsin & $\begin{array}{l}\mathrm{pH} 8.0,40^{\circ} \mathrm{C}, 4 \mathrm{~h}, \\
\text { total enzyme dose } 2.5 \%\end{array}$ & $2.11 \pm 0.11^{b}$ & $23.72 \pm 0.31^{c}$ & $62.38 \pm 1.67^{c}$ \\
\hline Pepsin & $\begin{array}{c}\mathrm{pH} 2.0,37^{\circ} \mathrm{C}, 4 \mathrm{~h}, \\
\text { total enzyme dose } 2.5 \%\end{array}$ & $1.99 \pm 0.07^{\mathrm{a}, \mathrm{b}}$ & $21.58 \pm 0.26^{c}$ & $55.47 \pm 2.02^{b}$ \\
\hline Neutrase & $\begin{array}{c}\mathrm{pH} 6.0,50{ }^{\circ} \mathrm{C}, 4 \mathrm{~h}, \\
\text { total enzyme dose } 2.5 \%\end{array}$ & $1.85 \pm 0.06^{\mathrm{a}}$ & $20.87 \pm 0.36^{b}$ & $50.67 \pm 1.85^{\mathrm{d}}$ \\
\hline
\end{tabular}

The yield and degree of hydrolysis (DH\%) of trypsin hydrolysate was $2.11 \pm 0.11 \mathrm{~g} / 100 \mathrm{~g}$ cartilage and $23.72 \% \pm 0.31 \%$, respectively, which was higher than for papain hydrolysate, alcalase hydrolysate, pepsin hydrolysate, and neutrase hydrolysate. The result indicated that trypsin could more effectively hydrolyze the proteins from scalloped hammerhead cartilages than the other four proteases. Furthermore, trypsin hydrolysate $(\mathrm{SHCH})$ showed a significantly higher HO• scavenging activity $(p<0.05)$ with $62.38 \% \pm 1.67 \%$ at $15 \mathrm{mg} / \mathrm{mL}$, whereas papain hydrolysate showed a significantly lower HO• scavenging activity $(p<0.05)$ at $34.85 \% \pm 1.05 \%$. Based on these data, the protein hydrolysate of scalloped hammerhead cartilage produced by trypsin was named $\mathrm{SHCH}$ and was selected for follow-up studies.

\subsection{Purification of the Antioxidant Peptides from $\mathrm{SHCH}$}

\subsubsection{Ultrafiltration}

Protein hydrolysate is a complex mixture of active and inactive peptides (of various sizes) and amino acid compositions, and ultrafiltration membrane technology is an important method for the fractionation of protein hydrolysate and the enrichment of peptides with specific MW ranges [1,5]. SHCH was fractionated by ultrafiltration using two molecular weight cut-off (MWCO) membranes (10 and $3 \mathrm{kDa})$, and three fractions, SHCH-I (MW < $3 \mathrm{kDa})$, SHCH-II (3 kDa < MW < $10 \mathrm{kDa})$, and SHCH-III (MW > $10 \mathrm{kDa}$ ), were prepared. As shown in Figure 1, the HO• scavenging activity of SHCH-I was $79.10 \% \pm 2.38 \%$ at $15 \mathrm{mg}$ protein $/ \mathrm{mL}$, which was significantly stronger than those of SHCH, SHCH-II, and SHCH-III ( $p<0.05)$. The MW of peptides plays a critical role in bioactivity, and protein hydrolysates with smaller MW usually exhibited higher antioxidant activity than larger MW hydrolysates [4,5]. SHCH-I, which is abundant in smaller MW peptides, showed high HO• scavenging activity, and the result was in agreement with other reports that the ultrafiltration fractions of protein hydrolysates with lower MW could more effectively interact with the free radicals interfering in oxidative processes [6,9]. 


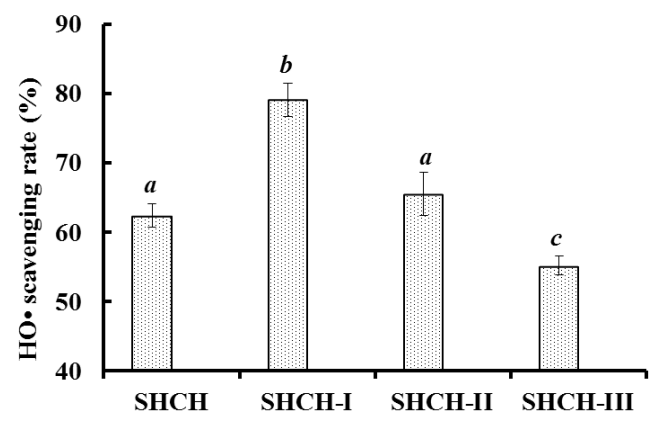

Figure 1. HO• scavenging activities of trypsin hydrolysate $(\mathrm{SHCH})$ and its three fractions at $15 \mathrm{mg}$ protein $/ \mathrm{mL}$. All data are presented as the mean \pm standard deviation (SD) of triplicate results. ${ }^{a-c}$ Values with same letters indicate no significant difference for each group of samples at the same concentration $(p>0.05)$.

\subsubsection{Anion-Exchange Chromatography}

Ion-exchange chromatography is used to separate the charged molecules based on their affinity to the ion exchanger (anion and/or cation exchange resins), and their interaction was determined by the number and location of the charges on the molecules [5]. SHCH-I was loaded onto a Diethylaminoethyl cellulose 52 (DEAE-52) cellulose anion-exchange column and separated by stepwise elution using deionized water and $0.1,0.5$, and $1.0 \mathrm{M} \mathrm{NaCl}$ (Figure 2A). Five separated fractions (Fr.1 to Fr.5) were collected. Their HO• scavenging activities were measured and are shown in Figure 2B. The HO• scavenging rate of Fr.4 reached $72.03 \% \pm 2.64 \%$ at $10 \mathrm{mg}$ protein $/ \mathrm{mL}$, and it exhibited significantly more efficient antioxidant activity than the other fractions $(p<0.05)$. Peptides with basic and/or hydrophobic amino acid residues, such as His, Lys and Pro, are thought to have strong antioxidant activities [24]. Therefore, anion and cation exchange resins have been widely used to purify antioxidant peptides from protein hydrolysates [25-27]. The present data showed that Fr.4 had the strongest HO• scavenging activity and was selected for further purification.
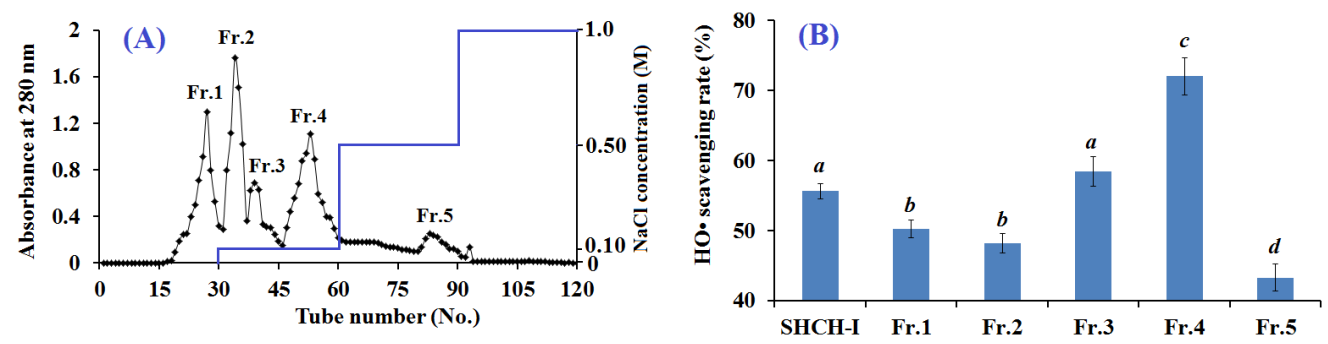

Figure 2. Elution profile of SHCH-I in DEAE-52 cellulose chromatography (A); and the HO• scavenging rate $(\%)$ of different fractions of $\mathrm{SHCH}-\mathrm{I}$ at $10 \mathrm{mg}$ protein $/ \mathrm{mL}(\mathbf{B})$. All data are presented as the mean \pm standard deviation (SD) of triplicate results. ${ }^{a-d}$ Values with same letters indicate no significant difference for each group of samples at the same concentration $(p>0.05)$. Fr: separated fractions.

\subsubsection{Gel Filtration Chromatography}

Molecular size is an important determinant of the bioactivity of a specific peptide [8]. Therefore, gel filtration chromatography is an important method to purify peptides. Fr.4 was loaded onto a Sephadex G-15 column and separated into two fractions of Fr.4-1 and Fr.4-2 (Figure 3A). Each fraction was collected, lyophilized, and evaluated for HO• scavenging activity. As shown in Figure 3B, the HO• scavenging rate of Fr.4-1 reached $87.80 \% \pm 2.24 \%$ at $5 \mathrm{mg}$ protein $/ \mathrm{mL}$ and was higher than those of Fr.4 (72.03\% $\pm 2.64 \%)$ and Fr.4-2 (52.38\% $\pm 1.62 \%)$. Therefore, Fr.4-1 was selected for further purification by RP-HPLC. 

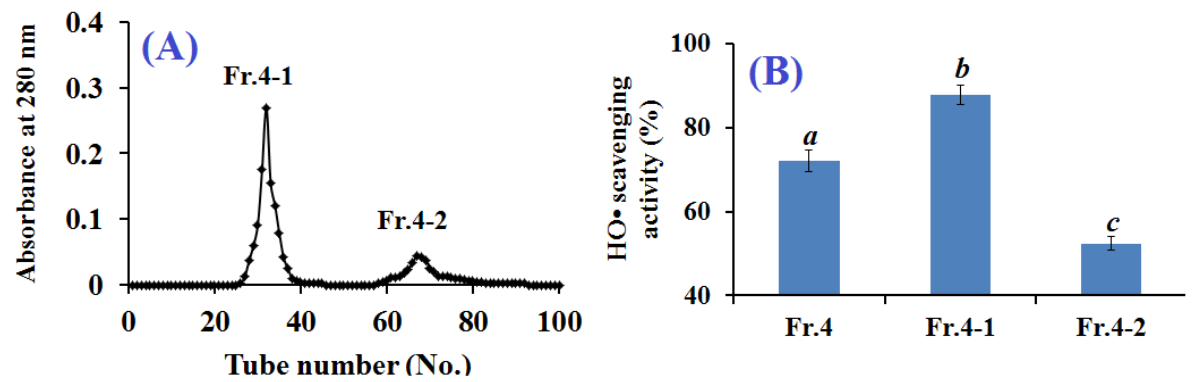

Figure 3. Elution profile of Fr.4 in Sephadex G-15 chromatography (A) and HO• scavenging activity of Fr.4 and its fractions at $5 \mathrm{mg}$ protein $/ \mathrm{mL}$ (B). All data are presented as the mean \pm SD of triplicate results. ${ }^{a-c}$ Values with same letters indicate no significant difference for each group of samples at the same concentration $(p>0.05)$.

\subsubsection{Isolation of Peptides from Fr.4-1 by Reversed-Phase High Performance Liquid} Chromatography (RP-HPLC)

The hydrophobic and hydrophilic properties of peptides play a key role in their retention time (RT) on an RP-HPLC column, and the RT can be adjusted by changing the ratio of polar (water) and nonpolar (methanol, acetonitrile) solvents [11]. Using an ultrafiltration membrane system, anion-exchange chromatography and gel filtration chromatography, Fr.4-1, which had the highest HO• scavenging activity among all fractions, was separated using RP-HPLC on a Zorbax C-18 column, and the eluted fractions were collected separately according to the chromatographic peaks (Figure 4). Three fractions, referred to as enzymolysis peptide of scalloped hammerhead cartilage A (SCPE-A), SCPE-B and SCPE-C, with RTs of 10.642, 13.605, and $17.979 \mathrm{~min}$, respectively, showed high antioxidant activities, and their $\mathrm{HO} \bullet$ scavenging rates reached $80.7 \% \pm 1.22 \%, 75.4 \% \pm 2.33 \%$, and $92.2 \% \pm 3.44 \%$, respectively, at $3.0 \mathrm{mg} / \mathrm{mL}$. Therefore, SCPE-A, SCPE-B and SCPE-C were collected for further research.

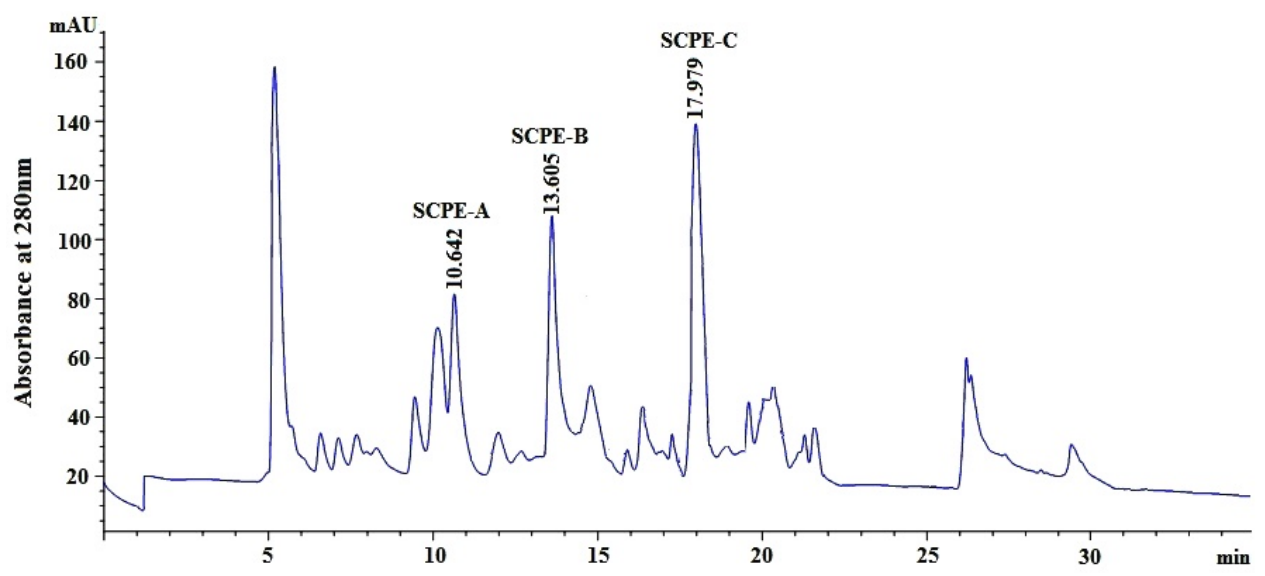

Figure 4. RP-HPLC profile of Fr.4-1 on a Zorbax C18 column with a linear gradient of acetonitrile $(0 \%-50 \%$ for $32 \mathrm{~min})$ containing $0.1 \%$ trifluoroacetic acid (TFA) at a flow rate of $0.8 \mathrm{~mL} / \mathrm{min}$.

\subsection{Molecular Mass and Amino Acid Sequences of the Purified Peptides}

The properties of peptides are related to their composition, structure, MW, amino acid sequence and hydrophobicity. Considering the radical-scavenging ability, the amino acid sequences and molecular mass of the three isolated peptides were analyzed using a protein sequencer and quadrupole-time of flight mass spectrometry (Q-TOF MS), respectively. The mass spectra of the three isolated peptides were shown in Figure 5. The amino acid sequences of SCPE-A, SCPE-B and SCPE-C were identified as Gly-Pro-Glu (GPE), Gly-Ala-Arg-Gly-Pro-Gln (GARGPQ), and Gly-Phe-Thr-Gly-Pro-Pro-Gly-Phe-Asn-Gly (GFTGPPGFNG), with molecular masses of $301.30 \mathrm{Da}$, 
584.64 Da and 950.03 Da, respectively, which were in agreement with the theoretical masses of 301.27 Da, $584.64 \mathrm{Da}$, and $949.12 \mathrm{Da}$, respectively.
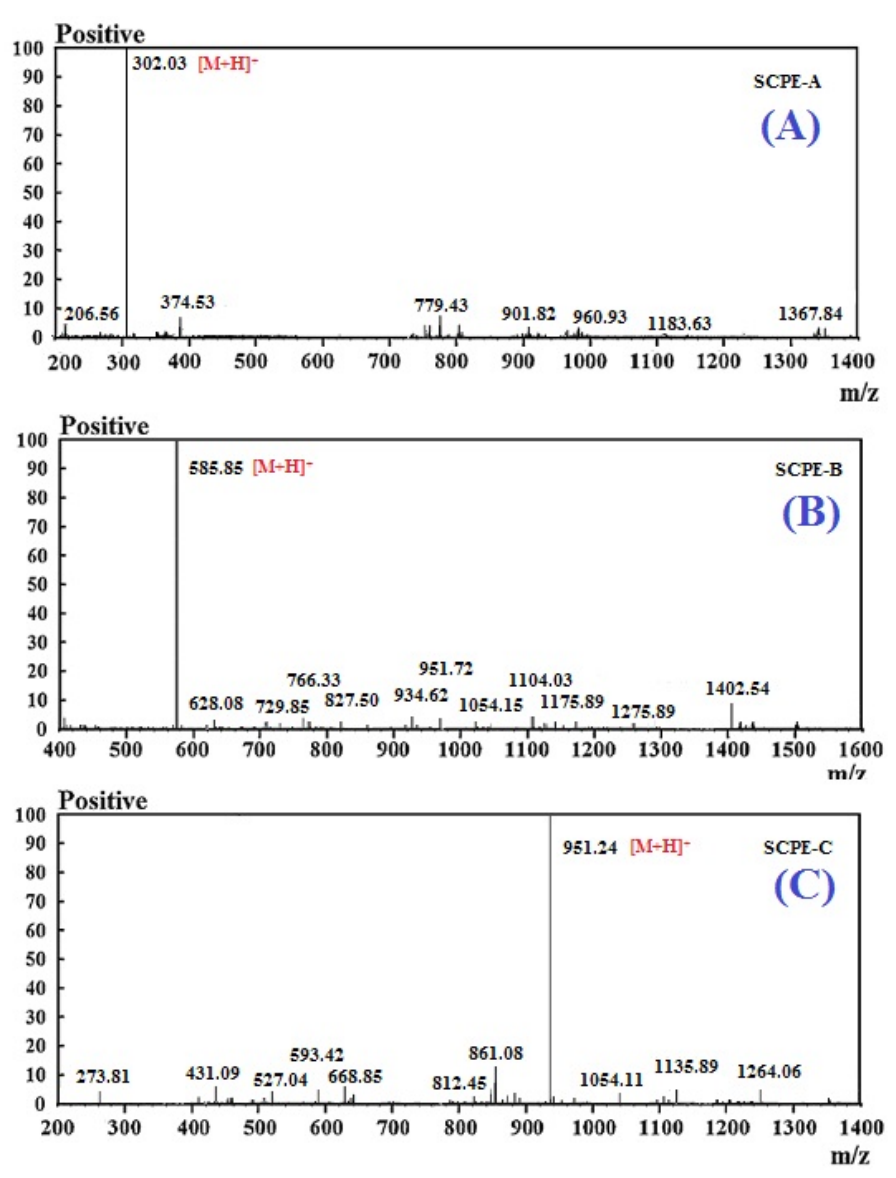

Figure 5. Mass spectrograms of SCPE-A, SCPE-B and SCPE-C.

\subsection{Antioxidant Activity of SCPE-A, SCPE-B and SCPE-C}

\subsubsection{DPPH• Scavenging Activity}

DPPH is a relatively stable organic radical that can be scavenged by accepting a proton-donating substance $\left(\mathrm{H}^{+}\right)$, which reduces the absorbance at $517 \mathrm{~nm}$ because the solution color changes from deep purple to yellow [19]. As shown in Figure 6A, SCPE-A, SCPE-B and SCPE-C showed dose-dependent anti-DPPH• activity, with $\mathrm{EC}_{50}$ values of $2.43,2.43$, and $1.99 \mathrm{mg} / \mathrm{mL}$, respectively, and SCPE-C exhibited the highest radical-scavenging activity among all samples, except the positive control of ascorbic acid. The $\mathrm{EC}_{50}$ of SCPE-C was lower than that of Pro-Ser-Tyr-Val (PSYV) (17.0 mg/mL) [28], Thr-Thr-Ala-Asn-Ile-Glu-Asp-Arg-Arg (TTANIEDRR) (2.503 mg/mL) [26], Phe-Leu-Asn-Glu-Phe-Leu-His-Val (FLNEFLHV) $(4.950$ mg/mL) [29], Trp-Glu-Gly-Pro-Lys (WEGPK) ( $4.438 \mathrm{mg} / \mathrm{mL})$, Gly-Val-Pro-Leu-Thr (GVPLT) $(4.541 \mathrm{mg} / \mathrm{mL})$ [5], Gly-Phe-Gly-Pro-Leu (GFGPL) (2.249 mg/mL), Val-Gly-Gly-Arg-Pro (VGGRP) (2.937 mg/mL) [30], FIMGPY (2.60 mg/mL), GPAGDY (3.48 mg/mL), IVAGPQ (3.93 mg/mL) [11], WDR(3.63 mg/mL), PYFNK (4.11 mg/mL) and LDK $(3.06 \mathrm{mg} / \mathrm{mL})[19,20]$ from the protein hydrolysates of loach, blue mussel, salmon, bluefin leatherjacket, grass carp skin, skate (Raja porosa) cartilage and scalloped hammerhead muscle, but it was higher than that of Gly-Ser-Gln (GSQ) $(0.61 \mathrm{mg} / \mathrm{mL})$ [31], Pro-Ile-Ile-Val-Tyr-Trp-Lys (PIIVYWK) $(0.713 \mathrm{mg} / \mathrm{mL})$, Phe-Ser-Val-Val-Pro-Ser-Pro-Lys (FSVVPSPK) $(0.937 \mathrm{mg} / \mathrm{mL}$ ) [29], Pro-Tyr-Ser-Phe-Lys (PYSFK) (1.575 mg/mL) [30], His-Phe-Gly-Asp-Pro-Phe-His (HFGDPFH) (0.20 mg/mL) [32], Phe-Leu-Pro-Phe (FLPF) $(0.789 \mathrm{mg} / \mathrm{mL})$, Leu-Pro-Phe (LPF) $(0.777 \mathrm{mg} / \mathrm{mL})$ and Leu-Leu-Pro-Phe 
(LLPF) (1.084 mg/mL) [33] from the protein hydrolysates of Chinese leek, blue mussel, grass carp skin, mussel sauce and corn gluten meal. Therefore, the present results suggested that SCPE-A, SCPE-B and $\mathrm{SCPE}-\mathrm{C}$ were DPPH$\bullet$ inhibitors and primary antioxidants that reacted with free radicals.
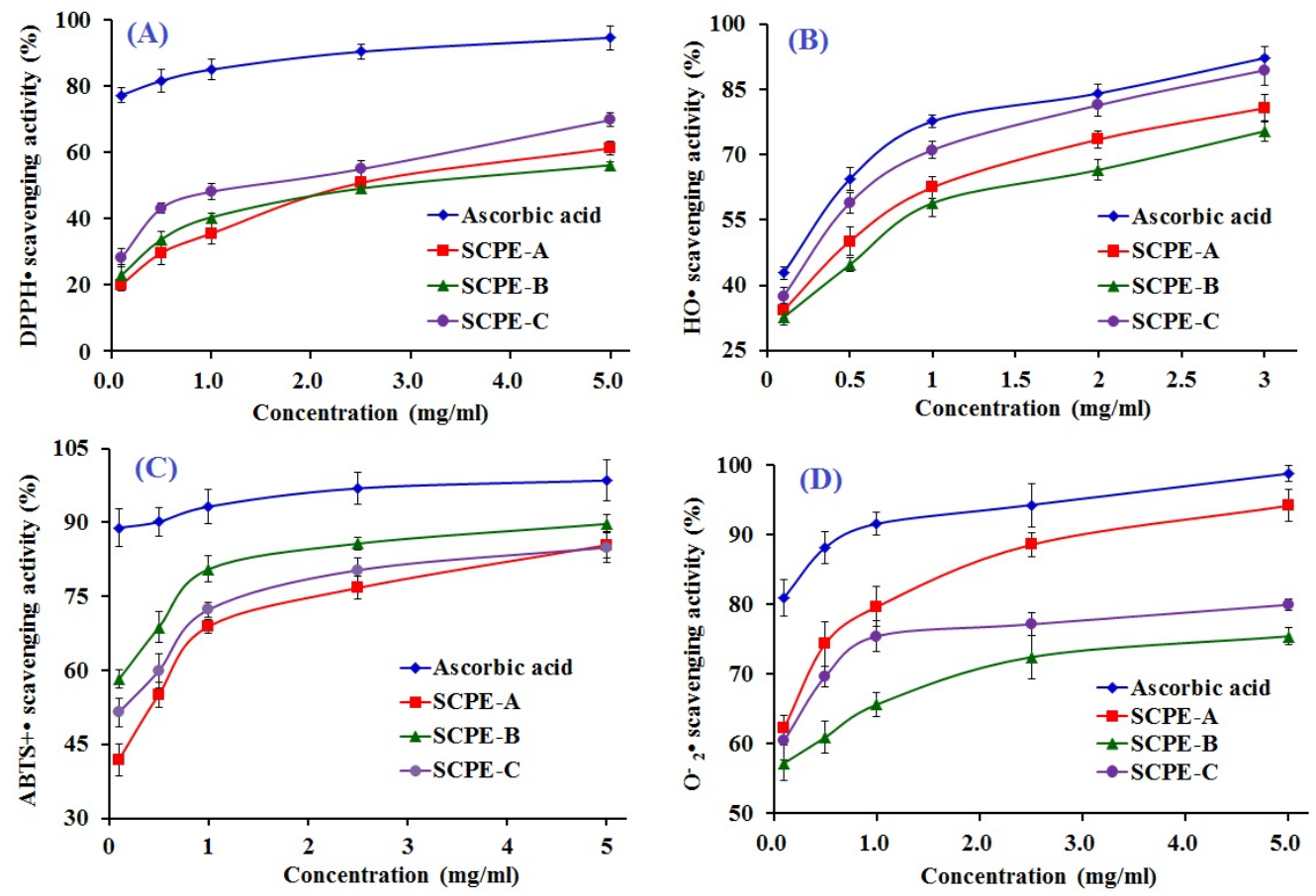

Figure 6. $\mathrm{DPPH} \bullet(\mathbf{A}) ; \mathrm{HO} \bullet(\mathbf{B}) ; \mathrm{ABTS}^{+} \bullet(\mathbf{C})$; and $\mathrm{O}_{2}^{-} \bullet$ (D) scavenging activities of SCPE-A, SCPE-B and SCPE-C. All data are presented as the mean \pm SD of triplicate results. DPPH•: 2,2-diphenyl-1-picrylhydrazyl radicals; $\mathrm{ABTS}^{+} \bullet$ : 2, 2'-azino-bis-3-ethylbenzothiazoline-6-sulfonic acid radicals; $\mathrm{O}_{2}^{-} \bullet$ : superoxide anion radicals.

\subsubsection{HO• Scavenging Activity}

$\mathrm{HO} \bullet$ is highly reactive and consequently short-lived and can damage virtually all types of macromolecules, including carbohydrates, nucleic acids, lipids, and proteins [5]. The HO• scavenging activity of SCPE-A, SCPE-B and SCPE-C was dose-dependent at the test concentrations, as shown in Figure 6B. The EC $_{50}$ values of SCPE-A, SCPE-B and SCPE-C were 0.28, 0.21, and $0.15 \mathrm{mg} / \mathrm{mL}$, respectively, and SCPE-C exhibited the highest HO• scavenging activity. The $\mathrm{EC}_{50}$ of SCPE-C was lower than that of PYFNK $(0.24 \mathrm{mg} / \mathrm{mL})$, LDK $(0.17 \mathrm{mg} / \mathrm{mL})[19,20]$, Leu-Gly-Leu-Asn-Gly-Asp-Asp-Val-Asn $\quad$ (LGLNGDDVN) $\quad(0.687 \quad \mathrm{mg} / \mathrm{mL}) \quad$ [34], PSYV (2.64 mg/mL) [28], HFGDPFH (0.50 mg/mL) [32], Phe-Pro-Glu-Leu-Leu-Ile (FPELLI) $(0.57 \mathrm{mg} / \mathrm{mL})$ and Val-Phe-Ala-Ala-Leu (VFAAL) $(0.31 \mathrm{mg} / \mathrm{mL})$ [4], as well as that of Tyr-Pro-Pro-Ala-Lys (YPPAK) (0.228 mg/mL) [23], Pro-Ser-Lys-Tyr-Glu-Pro-Phe-Val (PSKYEPFV) $(2.86 \mathrm{mg} / \mathrm{mL})$ [35], PYSFK (2.283 $\mathrm{mg} / \mathrm{mL})$, GFGPL (1.612 mg/mL), VGGRP (2.055 mg/mL) [30], Tyr-Leu-Gly-Ala-Lys (YLGAK) (scavenging rate: $45.14 \%$ at $0.5 \mathrm{mg} / \mathrm{mL}$ ), Gly-Gly-Leu-Glu-Pro-Ile-Asn-Phe-Gln (GGLEPINFQ) (scavenging rate: $41.07 \%$ at $0.5 \mathrm{mg} / \mathrm{mL}$ ) [36], Asn-Gly-Leu-Glu-Gly-Leu-Lys (NGLEGLK) (0.313 $\mathrm{mg} / \mathrm{mL}$ ), Asn-Ala-Asp-Phe-Gly-Leu-Asn-Gly-Leu-Glu-Gly-Leu-Ala (NADFGLNGLEGLA) (0.612 $\mathrm{mg} / \mathrm{mL}$ ) [32], FIMGPY (3.04), GPAGDY (3.92 mg/mL) and IVAGPQ (5.03 $\mathrm{mg} / \mathrm{mL})$ [11] from the protein hydrolysates of scalloped hammerhead muscle, conger eel, weatherfish loach, mussel sauce, Chinese cherry seeds, blue mussel, grass carp, egg white, giant squid and skate (R. porosa) cartilage. The three isolated peptides, especially SCPE-C, revealed good HO• scavenging activity, which demonstrated that it could serve as a scavenger to reduce or eliminate the damage induced by $\mathrm{HO} \bullet$ in foods and biological systems. 


\subsection{3. $\mathrm{ABTS}^{+} \bullet$ Scavenging Activity}

The $\mathrm{ABTS}^{+} \bullet$ scavenging assay is a sensitive method to determine the antioxidant capacity of bioactive compounds, in which sodium persulfate converts ABTS to its radical cation with a blue color and an absorption maximum of $734 \mathrm{~nm}$, and the blue $\mathrm{ABTS}^{+} \bullet$ is converted back to its colorless neutral form when $\mathrm{ABTS}^{+} \bullet$ is reactive towards an antioxidant $[10,37,38]$. The abilities of SCPE-A, SCPE-B and SCPE-C to scavenge $\mathrm{ABTS}^{+} \bullet$ in comparison with ascorbic acid were investigated, and dose-related effects were observed at different peptide concentrations ranging from 0 to $5.0 \mathrm{mg} / \mathrm{mL}$ (Figure 6C). SCPE-B, with an $\mathrm{EC}_{50}$ of $0.18 \mathrm{mg} / \mathrm{mL}$, showed the strongest scavenging activity on $\mathrm{ABTS}^{+} \bullet$ among the protein hydrolysate, fractions, and prepared peptides at all tested concentrations. The $\mathrm{EC}_{50}$ of SCPE-B was lower than those of WDR $(0.34 \mathrm{mg} / \mathrm{mL})$ [19], LDK $(0.19 \mathrm{mg} / \mathrm{mL})$ [20], FLNEFLHV $(1.548 \mathrm{mg} / \mathrm{mL})$ [29], FPELLI $(0.40 \mathrm{mg} / \mathrm{mL})$ and VFAAL $(0.38 \mathrm{mg} / \mathrm{mL})$ [4], FLPF $(1.497 \mathrm{mg} / \mathrm{mL})$, LPF $(1.013 \mathrm{mg} / \mathrm{mL}), \operatorname{LLPF}(1.031 \mathrm{mg} / \mathrm{mL})$ [33], GFGPL $(0.328 \mathrm{mg} / \mathrm{mL})$, VGGRP $(0.465 \mathrm{mg} / \mathrm{mL})$ [30], WEGPK (5.407 mg/mL), Gly-Pro-Pro (GPP) (2.472 mg/mL), GVPLT (3.124 mg/mL) [6], FIMGPY $(1.04 \mathrm{mg} / \mathrm{mL})$, GPAGDY $(0.77 \mathrm{mg} / \mathrm{mL})$ and IVAGPQ $(1.29 \mathrm{mg} / \mathrm{mL})$ [11] from the protein hydrolysates of scalloped hammerhead muscle, salmon, Chinese cherry seeds, corn gluten meal, grass carp skin, bluefin leatherjacket heads and skate cartilage. The present results indicated that SCPE-A, SCPE-B and SCPE-C could strongly donate electrons or hydrogen atoms to inactivate $\mathrm{ABTS}^{+} \bullet$.

\subsection{4. $\mathrm{O}_{2}^{-} \bullet$ Scavenging Activity}

$\mathrm{O}_{2}^{-} \bullet$ is the most common free radical and can produce hydrogen peroxide and hydroxyl radicals through dismutation and other reactions in vivo, which can cause damage to DNA, proteins and cell membranes. The $\mathrm{O}_{2}^{-} \bullet$ scavenging activities of SCPE-A, SCPE-B and SCPE-C were studied, and the dose-effect relations were observed as the concentration gradually increased from 0.1 to $5.0 \mathrm{mg} / \mathrm{mL}$ (Figure $6 \mathrm{D}$ ). The $\mathrm{EC}_{50}$ values of SCPE-A, SCPE-B and SCPE-C were 0.08, 0.14, and $0.11 \mathrm{mg} / \mathrm{mL}$, respectively. SCPE-A showed stronger $\mathrm{O}_{2}^{-} \bullet$ scavenging activity than SCPE-B and SCPE-C and reached $91.7 \% \pm 2.58 \%$ scavenging activity at $5.0 \mathrm{mg} / \mathrm{mL}$. The $\mathrm{EC}_{50}$ of SCPE-A was lower than that of WDR $(0.09 \mathrm{mg} / \mathrm{mL})$, PYFNK $(0.11 \mathrm{mg} / \mathrm{mL}), \operatorname{LDK}(0.12 \mathrm{mg} / \mathrm{mL})[19,20]$, HFGDPFH $(0.20 \mathrm{mg} / \mathrm{mL})$ [32], GSQ $(0.70 \mathrm{mg} / \mathrm{mL})$ [31], Ser-Leu-Pro-Ile-Gly-Leu-Met-Ile-Ala-Met (SLPIGLMIAM) $(0.3168 \mathrm{mg} / \mathrm{mL})$ [39], YLGAK (scavenging rate: $36.27 \%$ at $1.0 \mathrm{mg} / \mathrm{mL}$ ), GGLEPINFQ (scavenging rate: $32.05 \%$ at $1.0 \mathrm{mg} / \mathrm{mL}$ ) [36], His-Asp-His-Pro-Val-Cys (HDHPVC) $(0.265 \mathrm{mg} / \mathrm{mL}$ ) and His-Glu-Lys-Val-Cys (HEKVC) $(0.235 \mathrm{mg} / \mathrm{mL})$ [40], Tyr-Leu-Met-Arg (YLMR) $(0.450 \mathrm{mg} / \mathrm{mL})$, Val-Leu-Tyr-Glu-Glu (VLYEE) (0.693 mg/mL), Met-Ile-Leu-Met-Arg (MILMR) (0.993 mg/mL) [41], FIMGPY $(1.61 \mathrm{mg} / \mathrm{mL})$, GPAGDY $(1.66 \mathrm{mg} / \mathrm{mL})$ and IVAGPQ $(1.82 \mathrm{mg} / \mathrm{mL})$ [11] from the protein hydrolysates of scalloped hammerhead muscle, mussel sauce, Chinese leek seeds, Mytilus coruscus, egg white, round scad, croceine croaker muscle and skate cartilage. $\mathrm{O}_{2}^{-} \bullet$ could be catalyzed into hydrogen peroxide and oxygen by superoxide dismutase (SOD) with a reaction rate 10,000-fold higher than that of spontaneous dismutation in an organism [19]. Therefore, SCPE-A, SCPE-B and SCPE-C might have high antioxidant activity similar to SOD and could be applied as $\mathrm{O}_{2}^{-} \bullet$ scavengers in biological systems.

\subsubsection{Lipid Peroxidation Inhibition Assay}

Scavenging activities on DPPH•, $\mathrm{ABTS}^{+} \bullet, \mathrm{HO} \bullet$ and $\mathrm{O}_{2}^{-} \bullet$ have been widely used to assess the antioxidant capacities of protein hydrolysates and peptides. However, each of these assays only measures an antioxidant property representing a different mechanism, which does not reflect the multiple mechanisms by which samples may act as antioxidants to retard or inhibit lipid oxidation in a food system [42]. Therefore, in this section, the ability of the soluble samples to suppress lipid peroxidation in a linoleic acid model system was investigated. Lipid peroxidation is a complex process that involves the formation and propagation of lipid radicals and lipid hydroperoxides, which are formed as the primary oxidation products in the presence of oxygen [43]. The inhibitory activities of SCPE-A, SCPE-B and SCPE-C were measured by lipid peroxidation in an in vitro model and were 
compared with the commercially available antioxidant BHT for 7 days. Figure 7 shows that SCPE-A had a similar inhibitory effect on lipid peroxidation as BHT and significantly retarded the lipid peroxidation compared with the control (without sample), SCPE-B and SCPE-C. In previous research, SCPE-A showed excellent scavenging activity on DPPH $\bullet, \mathrm{HO} \bullet, \mathrm{ABTS}^{+} \bullet$ and $\mathrm{O}_{2}^{-} \bullet$, with $\mathrm{EC}_{50}$ values of $2.43,0.28,0.24$, and $0.08 \mathrm{mg} / \mathrm{mL}$, respectively. Therefore, the inhibition effect of lipid peroxidation caused by SCPE-A could be attributed to its radical-scavenging activity. In addition, SCPE-A may have potential applications in the food industry for retarding the production of unwanted off-flavors and toxic products.

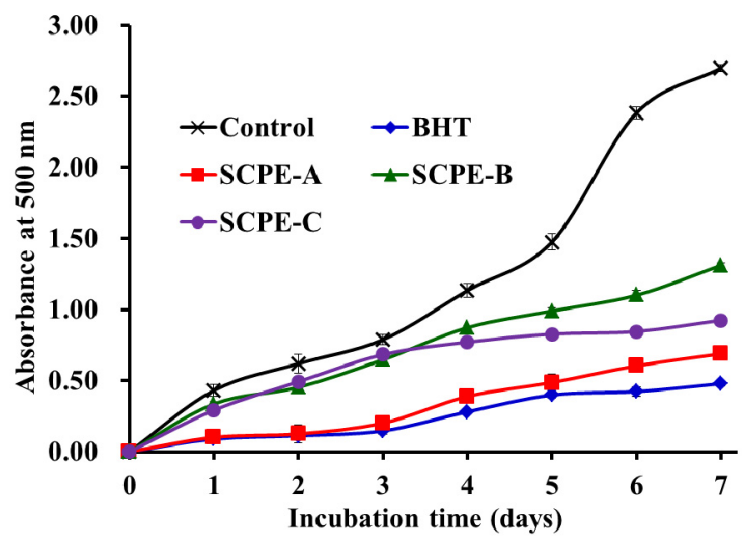

Figure 7. Lipid peroxidation inhibition assays of SCPE-A, SCPE-B and SCPE-C. All data are presented as the mean $\pm \mathrm{SD}$ of triplicate results.

\subsection{Structure-Antioxidant Activity Relationship of Peptides}

The structural characteristics of peptides provide guides for the evaluation of food-derived proteins as potential precursors of antioxidant peptides and predict the possible release of bioactive peptides from various proteins using an appropriate protease [1].

Many researchers found that the antioxidant activity of peptides was highly dependent on their amino acid sequence and composition. Chen et al. (2012) reported that the Gly residue may contribute significantly to antioxidant activity since the single hydrogen atom in the side chain of Gly serves as a proton-donating source and neutralizes active free radical species [44]. In addition, Nimalaratne et al. (2015) reported that the single hydrogen atom of Gly $(\mathrm{G})$ can provide high flexibility to the peptide backbone and positively influence the antioxidant properties [8]. Therefore, Gly residues might be important contributors to the antioxidant activity of SCPE-A, SCPE-B, and SCPE-C because there are one, two and four Gly residues in their amino acid sequences, respectively.

The pyrrolidine ring of proline $(\mathrm{P})$ can interact with the secondary structure of the peptide, thereby increasing the flexibility, and it is also capable of quenching singlet oxygen due to its low ionization potential [6]. Samaranayaka and Li-Chan (2011) reported that the Pro residue plays an important role in the antioxidant activity of the peptide purified from Saccharomyces cerevisiae protein hydrolysate [45]. Therefore, the one, one and two Pro residues in the amino acid sequences of SCPE-A, SCPE-B, and SCPE-C should enhance the radical-scavenging activities of the three peptides.

Aromatic amino acids, such as Phe, Tyr, His, and Trp, and hydrophobic amino acids, including Ala, Val, and Leu, have been reported to be critical to the antioxidant activities of peptides [1]. Huang et al. (2005) reported that amino acids with aromatic residues, such as Phe, Tyr and Trp, can quench free radicals by direct electron transfer [46]. The results from Guo et al. (2015) indicated that hydrophobic amino acids (e.g., Val, Ala, Leu) and aromatic amino acids (Phe, His, Tyr and Trp) can enhance the radical-scavenging abilities of peptides from Chinese cherry seeds [4]. Therefore, the presence of the one Ala residue and two Phe residues in the sequences of SCPE-B and SCPE-C, respectively, should have a positive impact on their radical-scavenging and lipid peroxidation inhibitory activities. 
The presence of acidic and basic amino acids plays a critical role in the metal ion chelating activity, which is related to the carboxyl and amino groups in their side chains [47]. Similar results were reported by Memarpoor-Yazdi et al. (2012), who found that the basic (Arg) and acidic (Asp and Glu) amino acid residues in the sequences of Asn-Thr-Asp-Gly-Ser-Thr-Asp-Tyr-Gly-Ile-Leu-Gln-Ile-Asn-Ser-Arg (NTDGSTDYGILQINSR) and Leu-Asp-Glu-Pro-Asp-Pro-Leu-Ile (LDEPDPLI) were critical to their antioxidant activities [48]. Díaz, et al. (2003) found that Glu is an effective cation chelator that forms complexes with calcium, iron and zinc and may contribute to the antioxidant activity [49]. Therefore, Glu in SCPE-A and Arg in SCPE-B might be favorable to their antioxidant activities.

In addition, the antioxidant activities of peptides are dependent on their molecular size, and shorter peptides, especially peptides with 2-10 amino acid residues, have stronger radical-scavenging and lipid peroxidation inhibition activities than their parent native proteins or long-chain peptides [1,46]. SCPE-A, SCPE-B, and SCPE-C exhibited good antioxidant activities in the radical scavenging and lipid peroxidation inhibition assays, which suggested that the short SCPE-A, SCPE-B, and SCPE-C could interact more effectively and easily with free radicals and inhibit the propagation cycles of lipid peroxidation in the radical scavenging and lipid peroxidation model system [50]. However, SCPE-A had the strongest $\mathrm{O}_{2}^{-} \bullet$ scavenging and lipid peroxidation inhibition activities, SCPE-B had the strongest scavenging activity on $\mathrm{ABTS}^{+} \bullet$, and SCPE-C exhibited the highest DPPH• and $\mathrm{HO} \bullet$ scavenging activities among all samples and fractions. The results indicated no consistent trends in the antioxidant capacities of SCPE-A, SCPE-B, and SCPE-C in different antioxidant assays. Therefore, more detailed study should be performed to clarify the relationship between the activity and structure of the three isolated peptides.

\section{Experimental Section}

\subsection{Chemicals and Reagents}

Scalloped hammerhead (S. lewini) was purchased from Fengmao market in Zhoushan City, Zhejiang Province, China. DEAE-52 cellulose and Sephadex G-15 were purchased from Shanghai Source Poly Biological Technology Co., Ltd. (Shanghai, China). Acetonitrile was of liquid chromatography (LC) grade and was purchased from Thermo Fisher Scientific Co., Ltd. (Shanghai, China). All other reagents used in the experiment were of analytical grade and were purchased from Sinopharm Chemical Reagent Co., Ltd. (Shanghai, China).

\subsection{Preparation of the Protein Hydrolysate from Scalloped Hammerhead Cartilage}

Frozen scalloped hammerhead cartilage was thawed, minced to homogenate and soaked in $1.0 \mathrm{M}$ guanidine hydrochloride with a solid-to-solvent ratio of $1: 5(w / v)$ for $48 \mathrm{~h}$ with continuous stirring, and the liquid supernatant was collected by centrifugation at $12,000 \times g$ at $4{ }^{\circ} \mathrm{C}$ for $10 \mathrm{~min}$. The resulting supernatant was dialyzed (MW $5 \mathrm{kDa}$ ) against 25 volumes of distilled water for $12 \mathrm{~h}$, with the solution changed every $4 \mathrm{~h}$, and the resulting dialysate was freeze-dried.

The freeze-dried sample was dissolved $(5 \% w / v)$ in $0.2 \mathrm{M}$ phosphate buffer solution (PBS, pH 7.2) and hydrolyzed for $4 \mathrm{~h}$ using neutrase at $\mathrm{pH} 7.0,60^{\circ} \mathrm{C}$; alcalase at $\mathrm{pH} 8.0,50{ }^{\circ} \mathrm{C}$; trypsin at $\mathrm{pH} 8.0$, $40{ }^{\circ} \mathrm{C}$; pepsin at $\mathrm{pH} 2.0,37^{\circ} \mathrm{C}$; or papain at $\mathrm{pH} 6.0,50^{\circ} \mathrm{C}$, with a total enzyme dose of $2.5 \%$. Enzymatic hydrolysis was stopped by heating for $10 \mathrm{~min}$ in boiling water, and the hydrolysate was centrifuged at $9000 \times g$ for $15 \mathrm{~min}$. The supernatant was freeze-dried and stored at $-20^{\circ} \mathrm{C}$ for further analysis. The protein hydrolysate of scalloped hammerhead cartilage using trypsin was named $\mathrm{SHCH}$.

\subsection{Isolation of Peptides from $\mathrm{SHCH}$}

\subsubsection{Fractionation of $\mathrm{SHCH}$ by Ultrafiltration}

SHCH was fractionated using ultrafiltration (8400, Millipore, Hangzhou, China) with $10 \mathrm{kDa}$ and $3 \mathrm{kDa}$ MW cutoff (MWCO) membranes (Millipore, Hangzhou, China). Three peptide fractions, named 
SHCH-I (MW < 3 kDa), SHCH-II $(3 \mathrm{kDa}<\mathrm{MW}<10 \mathrm{kDa})$ and SHCH-III $(\mathrm{MW}>10 \mathrm{kDa})$, were collected and lyophilized.

\subsubsection{Anion-Exchange Chromatography}

SHCH-I $(5 \mathrm{~mL}, 40.0 \mathrm{mg} / \mathrm{mL})$ was injected onto a DEAE-52 cellulose column $(1.6 \times 70 \mathrm{~cm})$ that was pre-equilibrated with deionized water and stepwise eluted with $150 \mathrm{~mL}$ distilled water and 0.1, 0.5 , and $1.0 \mathrm{M} \mathrm{NaCl}$ solution at a flow rate of $1.0 \mathrm{~mL} / \mathrm{min}$. Each eluted fraction $(5 \mathrm{~mL})$ was collected and measured at $280 \mathrm{~nm}$, and five fractions (Fr.1-5) were pooled and lyophilized.

\subsubsection{Gel filtration Chromatography}

Fr.4 $(5 \mathrm{~mL}, 10.0 \mathrm{mg} / \mathrm{mL})$ was fractionated on a Sephadex G-15 column $(2.6 \times 160 \mathrm{~cm})$ eluted with deionized water at a flow rate of $0.6 \mathrm{~mL} / \mathrm{min}$. Each eluate $(3 \mathrm{~mL})$ was collected and monitored at $280 \mathrm{~nm}$, and two fractions (Fr.4-1 and Fr.4-2) were lyophilized.

\subsubsection{RP-HPLC}

Fr.4-2 was separated by RP-HPLC (Agilent 1260 HPLC, Agilent Ltd., Santa Rosa, CA, USA) on a Thermo C-18 column $(4.6 \times 250 \mathrm{~mm}, 5 \mu \mathrm{m})$ (Thermo Co., Ltd., Yokohama, Japan) using a linear gradient of acetonitrile $(0 \%-50 \%$ in $0-32 \mathrm{~min})$ in $0.1 \%$ trifluoroacetic acid at a flow rate of $0.8 \mathrm{~mL} / \mathrm{min}$. The eluate was analyzed at $280 \mathrm{~nm}$, and three peptides (SCPE-A, SCPE-B and SCPE-C) were isolated and lyophilized.

\subsection{Determination of the Amino Acid Sequence and Molecular Mass}

The amino acid sequences of SCPE-A, SCPE-B and SCPE-C were determined on an Applied Biosystems 494 protein sequencer (Perkin Elmer/Applied Biosystems Inc., Foster City, CA, USA). The molecular masses were determined using a Q-TOF mass spectrometer coupled to an electrospray ionization source (ESI) (Micromass, Waters, Los Angeles, CA, USA).

\subsection{Degree of Hydrolysis (DH)}

DH analysis was performed according to the previously described method [49]. The hydrolysate $(50 \mu \mathrm{L})$ was mixed with $0.5 \mathrm{~mL}$ of $0.2 \mathrm{M}$ phosphate buffer, $\mathrm{pH} 8.2$ and $0.5 \mathrm{~mL}$ of $0.05 \%$ trinitrobenzenesulfonic acid (TNBS) reagent. TNBS was freshly prepared before use by diluting with DI water. The mixture was incubated at $50{ }^{\circ} \mathrm{C}$ for $1 \mathrm{~h}$ in a water bath. The reaction was stopped by adding $1 \mathrm{~mL}$ of $0.1 \mathrm{M} \mathrm{HCl}$ and incubating at room temperature for $30 \mathrm{~min}$. The absorbance was monitored at $420 \mathrm{~nm}$. L-leucine was used as a standard. To determine the total amino acid content, mungbean meal was completely hydrolyzed with $6 \mathrm{M} \mathrm{HCl}$ with a sample to acid ratio of 1:100 at $120^{\circ} \mathrm{C}$ for $24 \mathrm{~h}$. $\mathrm{DH}(\%)$ was calculated using the following equation:

$$
\mathrm{DH}=\left[\left(\mathrm{A}_{\mathrm{t}}-\mathrm{A}_{0}\right) /\left(\mathrm{A}_{\max }-\mathrm{A}_{0}\right)\right] \times 100
$$

where $A_{t}$ was the amount of a-amino acids released at time $t, A_{0}$ was the amount of a-amino acids in the supernatant at $0 \mathrm{~h}$, and $\mathrm{A}_{\max }$ was the total amount of a-amino acids obtained after acid hydrolysis at $120^{\circ} \mathrm{C}$ for $24 \mathrm{~h}$.

\subsection{Antioxidant Activity}

The radical $\left(\mathrm{DPPH} \bullet, \mathrm{HO} \bullet, \mathrm{O}_{2}^{-} \bullet\right.$, and $\mathrm{ABTS}^{+} \bullet$ ) scavenging activity and lipid peroxidation inhibition assays were performed according to previously reported methods [19,51], and the half elimination ratio $\left(\mathrm{EC}_{50}\right)$ was defined as the concentration of a sample that caused a $50 \%$ decrease in the initial concentration of DPPH $\bullet, \mathrm{O}_{2}^{-} \bullet, \mathrm{HO} \bullet$, and $\mathrm{ABTS}^{+} \bullet$. The $\mathrm{EC}_{50}$ was calculated based on the linear relationship of the radical-scavenging rate and concentration of the samples. 


\subsubsection{HO• Scavenging Activity}

In this system, hydroxyl radicals are generated by the Fenton reaction. Hydroxyl radicals can oxidize $\mathrm{Fe}^{2+}$ into $\mathrm{Fe}^{3+}$, and only $\mathrm{Fe}^{2+}$ can combine with 1,10-phenanthroline to form a red compound $\left(1,10-\right.$ phenanthroline- $\left.\mathrm{Fe}^{2+}\right)$ with the maximum absorbance at $536 \mathrm{~nm}$. The concentration of hydroxyl radical is reflected by the degree of decolorization of the reaction solution. Briefly, 1,10-phenanthroline solution $(1.0 \mathrm{~mL}, 1.865 \mathrm{mM})$ and the sample $(2.0 \mathrm{~mL})$ were added into a screw-capped tube and mixed. The $\mathrm{FeSO}_{4} \cdot 7 \mathrm{H}_{2} \mathrm{O}$ solution $(1.0 \mathrm{~mL}, 1.865 \mathrm{mM})$ was then pipetted into the mixture. The reaction was initiated by adding $1.0 \mathrm{~mL} \mathrm{H}_{2} \mathrm{O}_{2}(0.03 \% \mathrm{v} / \mathrm{v})$. After being incubated at $37^{\circ} \mathrm{C}$ for $60 \mathrm{~min}$ in a water bath, the absorbance of the reaction mixture was measured at $536 \mathrm{~nm}$ against a reagent blank. The reaction mixture without any antioxidant was used as the negative control, and mixture without $\mathrm{H}_{2} \mathrm{O}_{2}$ was used as the blank. The HO• scavenging activity was calculated by the following formula:

$$
\text { HO• scavenging activity }(\%)=\left[\left(A_{s}-A_{n}\right) /\left(A_{b}-A_{n}\right)\right] \times 100 \%
$$

where $A_{s}, A_{n}$, and $A_{b}$ were the absorbance values determined at $536 \mathrm{~nm}$ of the sample, the negative control, and the blank after reaction, respectively.

\subsubsection{DPPH• Scavenging Activity}

Two milliliters of deionized water containing different concentrations of samples were placed in cuvettes, and then $500 \mu \mathrm{L}$ of ethanol solution of DPPH $(0.02 \%)$ and $1.0 \mathrm{~mL}$ of ethanol were added into. A control sample containing DPPH solution without sample was also prepared. For the blank absorbance, DPPH solution was substituted with ethanol. The antioxidant activity of the sample was evaluated by the inhibition percentage of $\mathrm{DPPH} \bullet$ with the following equation:

$$
\mathrm{DPPH} \bullet \text { scavenging activity }(\%)=\left(\mathrm{A}_{0}+\mathrm{A}^{\prime}-\mathrm{A}\right) / \mathrm{A}_{0} \times 100 \%
$$

where A was sample absorbance rate; $A_{0}$ was the absorbance of control group; $A^{\prime}$ was the blank absorbance.

\subsection{3. $\mathrm{O}_{2}^{-} \bullet$ Scavenging Activity}

In the experiment, superoxide anions were generated in $1 \mathrm{~mL}$ of nitrotetrazolium blue chloride (NBT) $(2.52 \mathrm{mM}), 1 \mathrm{~mL}$ of nicotinamide adenine dinucleotide (NADH) $(624 \mathrm{mM})$ and $1 \mathrm{~mL}$ of different concentrations of samples. The reaction was initiated by adding $1 \mathrm{~mL}$ of phenazine methosulfate (PMS) solution $(120 \mu \mathrm{g})$ to the reaction mixture. The absorbance was measured at $560 \mathrm{~nm}$ against the corresponding blank after $5 \mathrm{~min}$ of incubation at $25^{\circ} \mathrm{C}$. The capacity of scavenging the $\mathrm{O}_{2}^{-} \bullet$ was calculated using the following equation:

$$
\mathrm{O}_{2}^{-} \bullet \text { scavenging activity }(\%)=\left[\left(\mathrm{A}_{\text {control }}-\mathrm{A}_{\text {sample }}\right) / \mathrm{A}_{\text {control }}\right] \times 100 \%
$$

where $\mathrm{A}_{\text {control }}$ was the absorbance without sample and $\mathrm{A}_{\text {sample }}$ was the absorbance with sample.

\subsection{4. $\mathrm{ABTS}^{+} \bullet$ Scavenging Activity}

The ABTS radical cation was generated by mixing ABTS stock solution $(7 \mathrm{mM})$ with potassium persulphate $(2.45 \mathrm{mM})$. The mixture was left in the dark at room temperature for $16 \mathrm{~h}$. The ABTS radical solution was diluted in $5 \mathrm{mM}$ phosphate buffered saline (PBS) $\mathrm{pH} 7.4$, to an absorbance of $0.70 \pm 0.02$ at $734 \mathrm{~nm}$. One milliliter of diluted ABTS radical solution was mixed with one milliliter of different concentrations of samples. Ten minutes later, the absorbance was measured at $734 \mathrm{~nm}$ 
against the corresponding blank. The $\mathrm{ABTS}^{+} \bullet$ scavenging activity of samples was calculated using the following equation:

$$
\mathrm{ABTS}^{+} \bullet \text { scavenging activity }(\%)=\left[\left(\mathrm{A}_{\text {control }}-\mathrm{A}_{\text {sample }}\right) / \mathrm{A}_{\text {control }}\right] \times 100 \%
$$

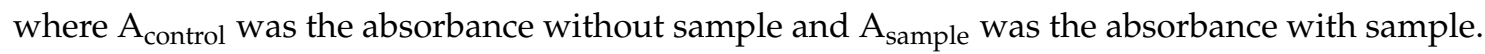

\subsubsection{Lipid Peroxidation Inhibition Assay}

A sample (5.0 mg) was dissolved in $10 \mathrm{~mL}$ of $50 \mathrm{mM}$ phosphate buffer ( $\mathrm{pH} 7.0$ ), and added to a solution of $0.13 \mathrm{~mL}$ of linoleic acid and $10 \mathrm{~mL}$ of $99.5 \%$ ethanol. Then, the total volume was adjusted to $25 \mathrm{~mL}$ with deionized water. The mixture was incubated in a conical flask with a screw cap at $40 \pm 1{ }^{\circ} \mathrm{C}$ in a dark room and the degree of oxidation was evaluated by measuring the ferric thiocyanate values. The reaction solution $(100 \mu \mathrm{L})$ incubated in the linoleic acid model system was mixed with $4.7 \mathrm{~mL}$ of $75 \%$ ethanol, $0.1 \mathrm{~mL}$ of $30 \%$ ammonium thiocyanate, and $0.1 \mathrm{~mL}$ of $20 \mathrm{mM}$ ferrous chloride solution in $3.5 \% \mathrm{HCl}$. After $3 \mathrm{~min}$, the thiocyanate value was measured by reading the absorbance at $500 \mathrm{~nm}$ following color development with $\mathrm{FeCl}_{2}$ and thiocyanate at different intervals during the incubation period at $40 \pm 1^{\circ} \mathrm{C}$.

\subsection{Statistical Analysis}

All experiments were performed in triplicate $(n=3)$, and the data are expressed as the mean \pm standard deviation (SD). ANOVA was applied to analyze the data using SPSS 19.0 (SPSS Corporation, Chicago, IL, USA). Duncan's multiple range test was used to measure the differences between the parameter means. The differences were considered significant if $p<0.05$.

\section{Conclusions}

In this study, three new antioxidant peptides (SCPE-A, SCPE-B and SCPE-C) were isolated from the protein hydrolysate of scalloped hammerhead (S. lewini) cartilage by ultrafiltration and chromatography, and their amino acid sequences were identified as Gly-Pro-Glu (GPE), Gly-Ala-Arg-Gly-Pro-Gln (GARGPQ), and Gly-Phe-Thr-Gly-Pro-Pro-Gly-Phe-Asn-Gly (GFTGPPGFNG). SCPE-A, SCPE-B and SCPE-C exhibited strong radical scavenging and lipid peroxidation inhibition activities. These results suggested that the purified peptides from the protein hydrolysate of scalloped hammerhead cartilage may be applied as ingredients in functional foods in bioactive food products. Our subsequent studies will focus on the molecular mechanisms and the relationship between the antioxidant activity and structure of the three isolated peptides.

Acknowledgments: This work was funded by the National Natural Science Foundation of China (NSFC) (No. 81673349) and the International Science and Technology Cooperation Program of China (No. 2012DFA30600).

Author Contributions: Bin Wang and Chang-Feng Chi conceived and designed the experiments. Xue-Rong Li and Li Li performed the experiments. Xue-Rong Li and Bin Wang analyzed the data. Chang-Feng Chi and Bin Wang contributed the reagents, materials, and analytical tools and wrote the paper.

Conflicts of Interest: The authors declare no conflicts of interest.

\section{References}

1. Sila, A.; Bougatef, A. Antioxidant peptides from marine by-products: Isolation, identification and application in food systems. A review. J. Funct. Foods 2016, 21, 10-26. [CrossRef]

2. Jang, H.L.; Liceaga, A.M.; Yoon, K.Y. Purification, characterisation and stability of an antioxidant peptide derived from sandfish (Arctoscopus japonicus) protein hydrolysates. J. Funct. Foods 2016, 20, $433-442$. [CrossRef]

3. Wattanasiritham, L.; Theerakulkait, C.; Wickramasekara, S.; Maier, C.S.; Stevens, J.F. Isolation and identification of antioxidant peptides from enzymatically hydrolyzed rice bran protein. Food Chem. 2016, 192, 156-162. [CrossRef] [PubMed] 
4. Guo, P.; Qi, Y.; Zhu, C.; Wang, Q. Purification and identification of antioxidant peptides from Chinese cherry (Prunus pseudocerasus Lindl.) seeds. J. Funct. Foods 2015, 19, 394-403. [CrossRef]

5. Chi, C.F.; Hu, F.Y.; Wang, B.; Li, Z.R.; Luo, H.Y. Influence of amino acid compositions and peptide profiles on antioxidant capacities of two protein hydrolysates from skipjack tuna (Katsuwonus pelamis) dark muscle. Mar. Drugs 2015, 13, 2580-2601. [CrossRef] [PubMed]

6. Mirzaei, M.; Mirdamadi, S.; Ehsani, M.R.; Aminlari, M.; Hosseini, E. Purification and identification of antioxidant and ACE-inhibitory peptide from Saccharomyces cerevisiae protein hydrolysate. J. Funct. Foods 2015, 19, 259-268. [CrossRef]

7. Wang, B.; Gong, Y.D.; Li, Z.R.; Yu, D.; Chi, C.F.; Ma, J.Y. Isolation and characterisation of five novel antioxidant peptides from ethanol-soluble proteins hydrolysate of spotless smoothhound (Mustelus griseus) muscle. J. Funct. Foods 2014, 6, 176-185. [CrossRef]

8. Nimalaratne, C.; Bandara, N.; Wu, J. Purification and characterization of antioxidant peptides from enzymatically hydrolyzed chicken egg white. Food Chem. 2015, 188, 467-472. [CrossRef] [PubMed]

9. Xing, L.; Hu, Y.; Hu, H.; Ge, Q.; Zhou, G.; Zhang, W. Purification and identification of antioxidative peptides from dry-cured Xuanwei ham. Food Chem. 2016, 194, 951-958. [CrossRef] [PubMed]

10. Xue, Z.; Wen, H.; Zhai, L.; Yu, Y.; Li, Y.; Yu, W.; Cheng, A.; Wang, C.; Kou, X. Antioxidant activity and anti-proliferative effect of a bioactive peptide from chickpea (Cicer arietinum L.). Food Res. Int. 2015, 77, 75-81. [CrossRef]

11. Pan, X.; Zhao, Y.Q.; Hu, F.Y.; Wang, B. Preparation and identification of antioxidant peptides from protein hydrolysate of skate (Raja porosa) cartilage. J. Funct. Foods 2016, 25, 220-230. [CrossRef]

12. Pan, X.; Zhao, Y.Q.; Hu, F.Y.; Chi, C.F.; Wang, B. Anticancer activity of a hexapeptide from skate (Raja porosa) cartilage protein hydrolysate in HeLa Cells. Mar. Drugs 2016, 14, 153. [CrossRef] [PubMed]

13. Guo, H.; Kouzuma, Y.; Yonekura, M. Structures and properties of antioxidative peptides derived from royal jelly protein. Food Chem. 2009, 113, 238-245. [CrossRef]

14. You, L.; Zhao, M.; Regenstein, J.M.; Ren, J. Purification and identification of antioxidative peptides from loach (Misgurnus anguillicaudatus) protein hydrolysate by consecutive chromatography and electrospray ionizationmass spectrometry. Food Res. Int. 2010, 43, 1167-1173. [CrossRef]

15. Kittiphattanabawon, P.; Benjakul, S.; Visessanguan, W.; Shahidi, F. Isolation and characterization of collagen from the cartilages of brownbanded bamboo shark (Chiloscyllium punctatum) and blacktip shark (Carcharhinus limbatus). LWT Food Sci. Technol. 2010, 43, 792-800. [CrossRef]

16. Zheng, L.; Ling, P.; Wang, Z.; Niu, R.; Hu, C.; Zhang, T.; Lin, X. A novel polypeptide from shark cartilage with potent anti-angiogenic activity. Cancer Biol. Ther. 2007, 6, 775-780. [CrossRef] [PubMed]

17. Liang, Q.; Wang, L.; Sun, W.; Wang, Z.; Xu, J.; Ma, H. Isolation and characterization of collagen from the cartilage of Amur sturgeon (Acipenser schrenckii). Process Biochem. 2014, 49, 318-323. [CrossRef]

18. Jeevithan, E.; Bao, B.; Bu, Y.S.; Zhou, Y.; Zhao, Q.B.; Wu, W.H. Type II collagen and gelatin from silvertip shark (Carcharhinus albimarginatus) cartilage: Isolation, purification, physicochemical and antioxidant properties. Mar. Drugs 2014, 12, 3852-3873. [CrossRef] [PubMed]

19. Wang, B.; Li, Z.R.; Chi, C.F.; Zhang, Q.H.; Luo, H.Y. Preparation and evaluation of antioxidant peptides from ethanol-soluble proteins hydrolysate of Sphyrna lewini muscle. Peptides 2012, 36, 240-250. [CrossRef] [PubMed]

20. Luo, H.Y.; Wang, B.; Li, Z.R.; Chi, C.F.; Zhang, Q.H.; He, G.Y. Preparation and evaluation of antioxidant peptide from papain hydrolysate of Sphyrna lewini muscle protein. LWT Food Sci. Technol. 2013, 51, 281-288. [CrossRef]

21. Li, Z.; Wang, B.; Chi, C.; Gong, Y.; Luo, H.; Ding, G. Influence of average molecular weight on antioxidant and functional properties of cartilage collagen hydrolysates from Sphyrna lewini, Dasyatis akjei and Raja porosa. Food Res. Int. 2013, 51, 283-293. [CrossRef]

22. Najafian, L.; Babji, A.S. Production of bioactive peptides using enzymatic hydrolysis and identification antioxidative peptides from patin (Pangasius sutchi) sarcoplasmic protein hydolysate. J. Funct. Foods 2014, 9, 280-289. [CrossRef]

23. Wang, B.; Li, L.; Chi, C.F.; Ma, J.H.; Luo, H.Y.; Xu, Y.F. Purification and characterisation of a novel antioxidant peptide derived from blue mussel (Mytilus edulis) protein hydrolysate. Food Chem. 2013, 138, 1713-1719. [CrossRef] [PubMed] 
24. Delgado, M.C.O.; Nardo, A.; Pavlovic, M.; Rogniaux, H.; Añón, M.C.; Tironi, V.A. Identification and characterization of antioxidant peptides obtained by gastrointestinal digestion of amaranth proteins. Food Chem. 2016, 197, 1160-1167. [CrossRef] [PubMed]

25. Liu, K.; Zhao, Y.; Chen, F.; Fang, Y. Purification and identification of Se-containing antioxidative peptides from enzymatic hydrolysates of Se-enriched brown rice protein. Food Chem. 2015, 187, 424-430. [CrossRef] [PubMed]

26. Park, S.Y.; Kim, Y.S.; Ahn, C.B.; Je, J.Y. Partial purification and identification of three antioxidant peptides with hepatoprotective effects from blue mussel (Mytilus edulis) hydrolysate by peptic hydrolysis. J. Funct. Foods 2016, 20, 88-95. [CrossRef]

27. Wu, Q.; Du, J.; Jia, J.; Kuang, C. Production of ACE inhibitory peptides from sweet sorghum grain protein using alcalase: Hydrolysis kinetic, purification and molecular docking study. Food Chem. 2016, 199, 140-149. [CrossRef] [PubMed]

28. You, S.J.; Wu, J.P. Angiotensin-I converting enzyme inhibitory and antioxidant activities of egg protein hydrolysates produced with gastrointestinal and nongastrointestinal enzymes. J. Food Sci. 2011, 76, 801-807. [CrossRef] [PubMed]

29. Ahn, C.B.; Kim, J.G.; Je, J.Y. Purification and antioxidant properties of octapeptide from salmon byproduct protein hydrolysate by gastrointestinal digestion. Food Chem. 2014, 147, 78-83. [CrossRef] [PubMed]

30. Cai, L.; Wu, X.; Zhang, Y.; Li, X.; Ma, S.; Li, J. Purification and characterization of three antioxidant peptides from protein hydrolysate of grass carp (Ctenopharyngodon idella) skin. J. Funct. Foods 2015, 16, $234-242$. [CrossRef]

31. Hong, J.; Chen, T.T.; Hu, P.; Yang, J.; Wang, S.Y. Purification and characterization of an antioxidant peptide (GSQ) from Chinese leek (Allium tuberosum Rottler) seeds. J. Funct. Foods 2014, 10, 1-10. [CrossRef]

32. Rajapakse, N.; Mendis, E.; Jung, W.K.; Je, J.Y.; Kim, S.K. Purification of a radical scavenging peptide from fermented mussel sauce and its antioxidant properties. Food Res. Int. 2005, 38, 175-182. [CrossRef]

33. Zhuang, H.; Tang, N.; Yuan, Y. Purification and identification of antioxidant peptides from corn gluten meal. J. Funct. Foods 2013, 5, 1810-1821. [CrossRef]

34. Ranathunga, S.; Rajapakse, N.; Kim, S.K. Purification and characterization of antioxidative peptide derived from muscle of conger eel (Conger myriaster). Eur. Food Res. Technol. 2006, 222, 310-315. [CrossRef]

35. Ren, J.; Zhao, M.; Shi, J.; Wang, J.; Jiang, Y.; Cui, C.; Kakuda, Y.; Xue, S.J. Purification and identification of antioxidant peptides from grass carp muscle hydrolysates by consecutive chromatography and electrospray ionization-mass spectrometry. Food Chem. 2008, 108, 727-736. [CrossRef] [PubMed]

36. Chen, C.; Chi, Y.J.; Zhao, M.Y.; Lv, L. Purification and identification of antioxidant peptides from egg white protein hydrolysate. Amino Acids 2012, 43, 457-466. [CrossRef] [PubMed]

37. Re, R.; Pellegrini, N.; Proteggente, A.; Pannala, A.; Yang, M.; Rice-Evans, C. Antioxidant activity applying an improved ABTS radical cation decolorization assay. Free Radic. Biol. Med. 1999, 26, 1231-1237. [CrossRef]

38. Zheng, L.; Zhao, M.; Xiao, C.; Zhao, Q.; Su, G. Practical problems when using ABTS assay to assess the radical-scavenging activity of peptides: Importance of controlling reaction $\mathrm{pH}$ and time. Food Chem. 2016, 192, 288-294. [CrossRef] [PubMed]

39. Kim, E.K.; Oh, H.J.; Kim, Y.S.; Hwang, J.W.; Ahn, C.B.; Lee, J.S.; Jeon, Y.J.; Moon, S.H.; Sung, S.H.; Jeon, B.T.; et al. Purification of a novel peptide derived from Mytilus coruscus and in vitro/in vivo evaluation of its bioactive properties. Fish Shellfish Immunol. 2013, 34, 1078-1084. [CrossRef] [PubMed]

40. Jiang, H.; Tong, T.; Sun, J.; Xu, Y.; Zhao, Z.; Liao, D. Purification and characterization of antioxidative peptides from round scad (Decapterus maruadsi) muscle protein hydrolysate. Food Chem. 2014, 154, 158-163. [CrossRef] [PubMed]

41. Chi, C.F.; Hu, F.Y.; Wang, B.; Ren, X.J.; Deng, S.G.; Wu, C.W. Purification and characterization of three antioxidant peptides from protein hydrolyzate of croceine croaker (Pseudosciaena crocea) muscle. Food Chem. 2015, 168, 662-667. [CrossRef] [PubMed]

42. Conway, V.; Gauthier, S.F.; Pouliot, Y. Antioxidant activities of buttermilk proteins, whey proteins, and their enzymatic hydrolysates. J. Agric. Food Chem. 2013, 61, 364-372. [CrossRef] [PubMed]

43. Hu, F.Y.; Chi, C.F.; Wang, B.; Deng, S.G. Two novel antioxidant nonapeptides from protein hydrolysate of skate (Raja porosa) muscle. Mar. Drugs 2015, 13, 1993-2009. [CrossRef] [PubMed] 
44. Chen, C.; Chi, Y.J.; Zhao, M.Y.; Xu, W. Influence of degree of hydrolysis on functional properties, antioxidant and ACE inhibitory activities of egg white protein hydrolysate. Food Sci. Biotechnol. 2012, 21, 27-34. [CrossRef]

45. Samaranayaka, A.G.P.; Li-Chan, E.C.Y. Food-derived peptidic antioxidants: A review of their production, assessment, and potential applications. J. Funct. Foods 2011, 3, 229-254. [CrossRef]

46. Huang, D.; Ou, B.; Prior, R.L. The chemistry behind antioxidant capacity assays. J. Agric. Food Chem. 2005, 53, 1841-1856. [CrossRef] [PubMed]

47. Gimenez, B.; Aleman, A.; Montero, P.; Gomez-Guillen, M.C. Antioxidant and functional properties of gelatin hydrolysates obtained from skin of sole and squid. Food Chem. 2009, 114, 976-983. [CrossRef]

48. Memarpoor-Yazdi, M.; Asoodeh, A.; Chamani, J. A novel antioxidant and antimicrobial peptide from hen egg white lysozyme hydrolysates. J. Funct. Foods 2012, 4, 278-286. [CrossRef]

49. Díaz, M.; Dunn, C.M.; McClements, D.J.; Decker, E.A. Use of caseinophosphopeptides as natural antioxidants in oil-in-water emulsions. J. Agric. Food Chem. 2003, 51, 2365-2370. [CrossRef] [PubMed]

50. Wiriyaphan, C.; Xiao, H.; Decker, E.A.; Yongsawatdigul, J. Chemical and cellular antioxidative properties of threadfin bream (Nemipterus spp.) surimi byproduct hydrolysates fractionated by ultrafiltration. Food Chem. 2015, 167, 7-15. [CrossRef] [PubMed]

51. Wang, B.; Wang, Y.M.; Chi, C.F.; Hu, F.Y.; Deng, S.G.; Ma, J.Y. Isolation and characterization of collagen and antioxidant collagen peptides from scales of croceine croaker (Pseudosciaena crocea). Mar. Drugs 2013, 11, 4641-4661. [CrossRef] [PubMed]

(C) 2017 by the authors. Licensee MDPI, Basel, Switzerland. This article is an open access article distributed under the terms and conditions of the Creative Commons Attribution (CC BY) license (http:/ / creativecommons.org/licenses/by/4.0/). 